\title{
Effects of basic fibroblast growth factor and nerve growth factor on lactate production, $\gamma$-glutamyl transpeptidase and aromatase activities in cultured Sertoli cells
}

\author{
Helena F Schteingart, Silvina B Meroni, Daniela F Cánepa, Eliana H Pellizzari and Selva B Cigorraga \\ Centro de Investigaciones Endocrinológicas (CEDIE), Hospital de Niños 'Ricardo Gutiérrez', Gallo 1330 (1425) Buenos Aires, Argentina \\ (Correspondence should be addressed to S B Cigorraga; Email: CEDIE@pccp.com.ar)
}

\begin{abstract}
Sertoli cells are under the control of FSH and androgens and also respond to polypeptidic factors locally produced. Basic fibroblast growth factor (bFGF) and nerve growth factor (NGF) have been proposed to belong to the large set of intratesticular regulators. The aim of the present investigation was to analyze the effects of bFGF and NGF on lactate production, $\gamma$-glutamyl transpeptidase $(\gamma$-GTP) and aromatase activities. Cultured Sertoli cells dose-dependently responded to bFGF by increasing lactate production and $\gamma$-GTP activity under basal conditions. In FSH-stimulated cultures, a synergistic effect of FSH with bFGF for lactate production was observed. NGF did not produce changes in lactate production or $\gamma$-GTP activity at any dose tested. Both peptides decreased FSH-stimulated aromatase activity.

These results provide additional evidence for the participation of bFGF and NGF in the complex network of intratesticular regulators. bFGF has pleiotropic effects on Sertoli cell function while the actions of NGF seem to be more limited.
\end{abstract}

European Journal of Endocrinology 141 539-545

\section{Introduction}

The testis is a complex organ organized into two compartments: the tubular compartment and the interstitium. In the tubular compartment Sertoli cells play a pivotal role in testicular function; particularly the one associated with the production of a sufficient number of spermatozoa to attain fertility. To accomplish the latter objective, the Sertoli cell not only senses the levels of FSH and androgens but also responds to multiple locally produced polypeptidic factors by modulating its metabolic activity. In this way the Sertoli cell leads to the constitution of a specific biochemical and cytoarchitectural microenvironment in the adluminal compartment where germ cells will proliferate and differentiate $(1,2)$.

Among Sertoli cell functions which might be of interest to germ cell development are the provision of adequate levels of energy substrates and protection against oxidative injury. Lactate production in Sertoli cells has been shown to be under the control of folliclestimulating hormone (FSH) (3), insulin, insulin-like growth factor-I (IGF-I) and IGF-II $(4,5)$, transforming growth factor- $\beta$ (TGF $\beta)$ (6) and, more recently, it has been shown that tumor necrosis factor- $\alpha(\mathrm{TNF} \alpha)$ is also involved in its production (7). Reduced glutathione is a powerful scavenger of reactive oxygen species and toxic chemicals, which is used by many tissues in the detoxification of electrophilic compounds and cellular protection against oxidative stress $(8,9), \gamma$-Glutamyl transpeptidase $(\gamma$-GTP) is a key enzyme in glutathione metabolism $(10,11)$. It has been shown that Sertoli cell $\gamma$-GTP activity is under the influence of FSH and germ cell derived products $(12,13)$.

In the last two decades a large body of studies have analyzed local production, expression of specific receptors and biological actions of different peptidic factors in the testis (14). Basic fibroblast growth factor (bFGF) and nerve growth factor (NGF) have been proposed as part of this complicated network of intratesticular regulators. bFGF belongs to a family of at least 12 polypeptides widely distributed in many tissues and exhibiting a variety of actions (15). It has been shown that bFGF increases c-fos and transferrin mRNA in cultured rat Sertoli cells $(16,17)$. NGF is a protein essential for the development and maintenance of sensory and sympathetic neurons of the peripheral nervous system (18). NGF and its receptors have been found not only in the nervous system but also in other organs, including the testis (19-22). It has been shown that infusion of NGF into adult rat testis in vivo causes an increase in the level of testicular androgen binding protein (ABP) mRNA (23). More recently NGF has been shown to be involved in Sertoli cell interleukin 6 (IL-6) secretion (24). 
The aim of the present investigation was to analyze the effects of bFGF and NGF on three Sertoli cell metabolic functions, lactate production, $\gamma$-GTP and aromatase activities.

\section{Materials and methods Materials}

Ovine FSH (NIH-oFSH-S-16) was obtained from the National Hormone and Pituitary Program, National Institute of Diabetes, Digestive and Kidney Diseases (NIDDK), Bethesda, MD, USA. Tissue culture media and bFGF (Human Recombinant) were purchased from Grand Island Biological Co. (Grand Island, NY, USA). Nerve growth factor- $\beta$ (NGF; from mouse submaxillary glands) and all other drugs and reagents were purchased from Sigma Chemical Co. (St Louis, MO, USA).

\section{Sertoli cell isolation and culture}

Sertoli cells from 20-day-old Sprague-Dawley rats were isolated as previously described (13). Briefly, decapsulated testes were digested with $0.1 \%$ collagenase and $0.006 \%$ soybean trypsin inhibitor in Hanks' balanced salt solution (HBSS) for $5 \mathrm{~min}$ at room temperature. Seminiferous tubules were saved, cut and submitted to $1 \mathrm{~mol} / \mathrm{l}$ glycine $-2 \mathrm{mmol} / \mathrm{l}$ EDTA $(\mathrm{pH} 7.4$ ) treatment to remove peritubular cells. The washed tubular pellet was then digested again with collagenase for $10 \mathrm{~min}$ at room temperature to remove germinal cells. The Sertoli cell suspension, collected by sedimentation, was resuspended in culture medium which comprised a 1:1 mixture of Ham's F-12 and Dulbecco's modified Eagle medium, supplemented with $20 \mathrm{mmol} / \mathrm{l}$ Hepes, $1.8 \mathrm{mg} /$ $\mathrm{ml}$ sodium bicarbonate, $100 \mathrm{IU} / \mathrm{ml}$ penicillin, $2.5 \mu \mathrm{g} / \mathrm{ml}$ amphotericin B, $10 \mu \mathrm{g} / \mathrm{ml}$ transferrin, $5 \mu \mathrm{g} / \mathrm{ml}$ insulin, $5 \mu \mathrm{g} / \mathrm{ml}$ vitamin E and $4 \mathrm{ng} / \mathrm{ml}$ hydrocortisone. Sertoli cells were cultured in 24 multiwell plates at $34^{\circ} \mathrm{C}$ in a mixture of $5 \% \mathrm{CO}_{2}: 95 \%$ air.

Purity of Sertoli cells reached 95\% after 5 days in culture as seen by phase contrast microscopy. No myoid cell contamination was revealed when an immunoperoxidase technique was applied to Sertoli cell cultures using a specific antiserum to alpha-smooth muscle actin. Remaining cell contaminants were of germ cell origin.

\section{Culture conditions}

Sertoli cells were allowed to attach for $48 \mathrm{~h}$ in the presence of insulin $(5 \mu \mathrm{g} / \mathrm{ml})$ and medium was replaced at this time with fresh medium without insulin; variable doses of bFGF or NGF and/or FSH $(100 \mathrm{ng} / \mathrm{ml})$ were added on day 3 as indicated in figure legends. Culture medium was changed $72 \mathrm{~h}$ later (day 6). The $72 \mathrm{~h}$ conditioned media obtained on day 6 were used to evaluate transferrin and lactate levels. Medium with the corresponding stimuli was replaced and cultures were allowed to proceed for an additional 24h. $\gamma$-GTP activity was determined on the cells harvested on day 7. In parallel cultures, cells were maintained under basal conditions until the sixth day and bFGF or NGF were added with the aromatization mixture to evaluate aromatase activity. On day 7 media were collected and saved for estradiol determinations.

\section{$\gamma$-Glutamyl transpeptidase (GTP) assay}

$\gamma$-GTP activity was assayed by the method of Orlowsky and Meister (25) using L- $\gamma$-glutamyl $p$-nitroanilide as substrate and glycylglycine as the acceptor molecule. Sertoli cell monolayers were disrupted by ultrasonic irradiation in $0.5 \mathrm{ml}$ reaction buffer $(0.1 \mathrm{~mol} / \mathrm{l}$ Tris buffer, $0.01 \mathrm{~mol} / \mathrm{I} \mathrm{MgCl}_{2}, 0.02 \mathrm{~mol} / \mathrm{lglycylglycine}, \mathrm{pH} 9$ ). Adequate aliquots for DNA determinations were saved and $5 \mathrm{mmol} / \mathrm{l}$ substrate (L- $\gamma$-glutamyl $p$-nitroanilide) was added to the remaining material. The reaction was allowed to proceed for $120 \mathrm{~min}$ at $34^{\circ} \mathrm{C}$, and the enzymatic reaction was stopped by addition of acetic acid to $1 \mathrm{~mol} / \mathrm{l}$ concentration. Samples were then centrifuged and absorbances determined in a spectrophotometer at $410 \mathrm{~nm}$. Values were compared against a standard curve with increasing concentrations of p-nitroaniline.

\section{Lactate determination}

Lactate was measured by a standard method involving conversion of $\mathrm{NAD}^{+}$to $\mathrm{NADH}$ determined as the rate of increase of absorbance at $340 \mathrm{~nm}$ wavelength. A commercial kit from Sigma Chemical Co. (St Louis, MO, USA) was used.

\section{Transferrin determination}

Rat transferrin (rTrf) was measured by RIA as described by Handelsman et al. (26). A polyclonal antibody raised against rat transferrin in rabbits was used (Cappel Laboratories, Cochranville, PA, USA). The cross-reactivity of human transferrin in this assay is less than $0.003 \%$. Unconditioned medium containing $10 \mu \mathrm{g} / \mathrm{ml}$ human transferrin did not show any crossreactivity in this assay. This RIA has a sensitivity of $3 \mathrm{ng} /$ tube and intra- and interassay coefficients of variation of $7 \%$ and $16 \%$ respectively.

\section{Aromatase activity}

To evaluate aromatase activity, $100 \mathrm{ng} / \mathrm{ml} \mathrm{FSH}$ and $3 \mu \mathrm{mol} / \mathrm{l}$ testosterone as substrate for aromatization were added on the sixth day with the medium change. Media were collected $24 \mathrm{~h}$ later (day 7), centrifuged at $1100 \mathrm{~g}$ for $10 \mathrm{~min}$ and stored at $-20^{\circ} \mathrm{C}$ until estradiol $\left(\mathrm{E}_{2}\right)$ determinations were performed. The monolayers were washed with $0.9 \% \mathrm{NaCl}$ solution and $0.5 \mathrm{ml}$ of 
$2 \mathrm{mmol} / \mathrm{l}$ EDTA (pH 7.4) was added. Cells were disrupted by ultrasonic irradiation and adequate aliquots for DNA determinations were saved.

\section{Other assays}

DNA was determined by the method of Labarca and Paigen (27). RIA of estradiol was performed according to the method of Escobar et al. (28) using a specific antibody which cross-reacts less than $1 \%$ with estrone and estriol. The RIA has a sensitivity of $6.25 \mathrm{pg} /$ tube and intra- and interassay coefficients of variation of $8 \%$ and $15 \%$ respectively.

\section{Statistical analysis}

Statistical analysis was performed by analysis of variance followed by Tukey's protected $t$-test for comparison of data

A

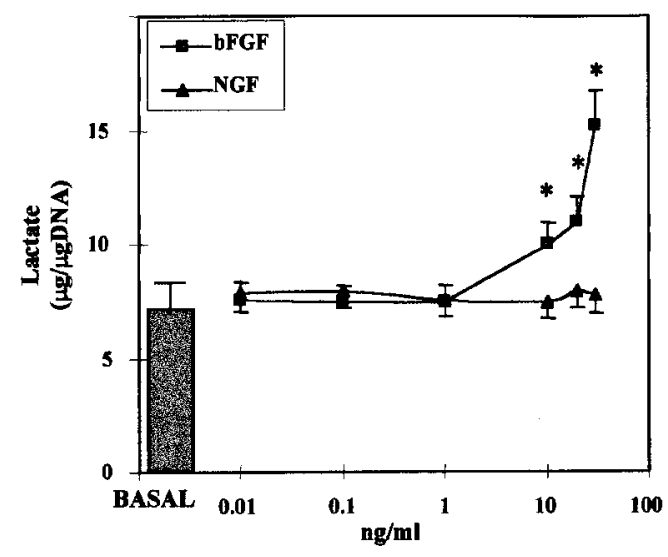

B

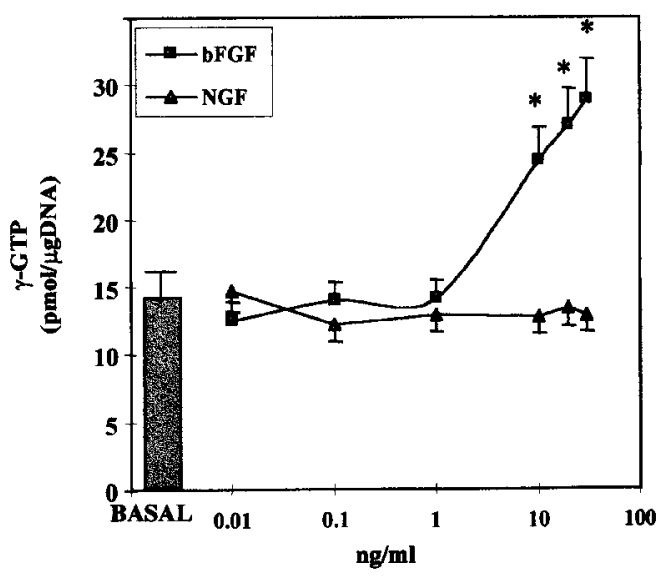

from multiple groups using the GB-STAT version 4.0 statistical program (Dynamic Microsystems, Inc., Silver Spring, MD, USA).

\section{Results}

\section{Effect of bFGF and NGF on basal lactate production and $\gamma$-GTP activity}

Figure $1 \mathrm{~A}$ and $\mathrm{B}$ shows dose-response curves to bFGF and NGF for basal lactate production and $\gamma$-GTP activity respectively. bFGF dose-dependently increased lactate production with doses higher than $10 \mathrm{ng} / \mathrm{ml}$ while NGF had no effect at any dose tested. Similarly, bFGF stimulated $\gamma$-GTP activity while NGF had no effect on it.

Table 1 summarizes the results obtained in five different experiments with $10 \mathrm{ng} / \mathrm{ml} \mathrm{bFGF}$ and $10 \mathrm{ng} / \mathrm{ml} \mathrm{NGF}$.
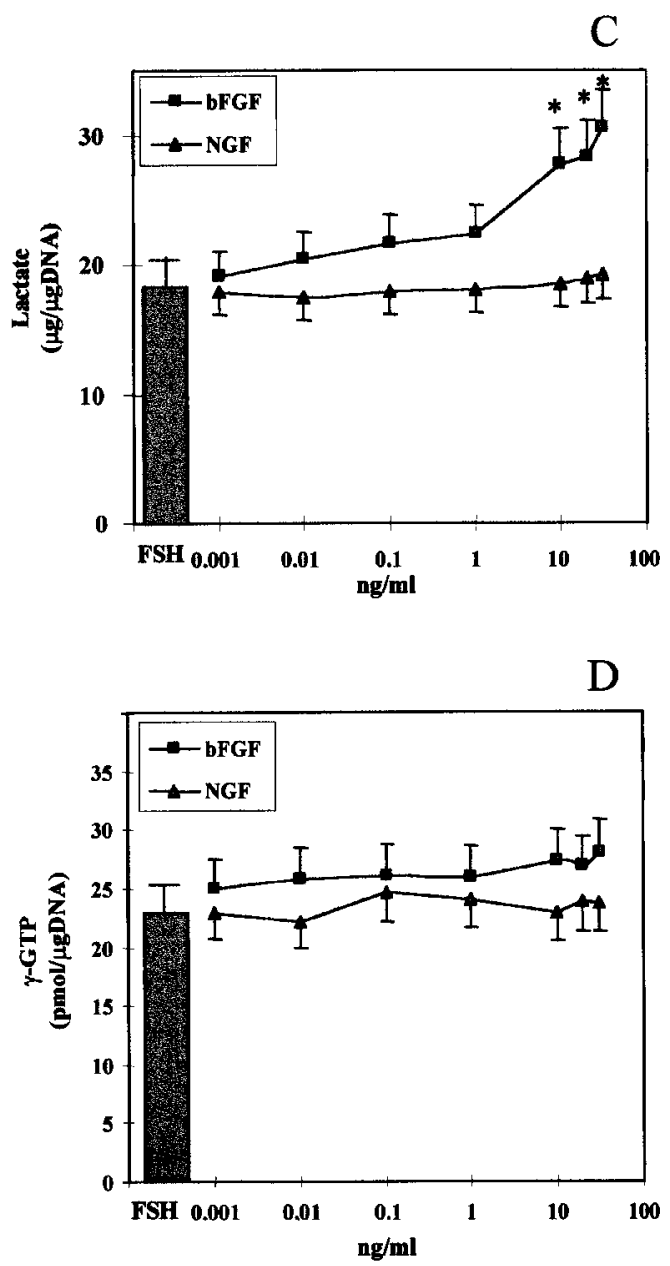

Figure 1 Dose-response curves of lactate production $((A)$ and $(C))$ and $\gamma$-GTP activity $((B)$ and $(D))$ to bFGF and NGF stimulation. Sertoli cells were cultured for 3 days in the presence of variable doses of bFGF or NGF $(0.01,0.1,1,10,20$ and $30 \mathrm{ng} / \mathrm{ml})$, under basal ((A) and (B)) or $\mathrm{FSH}$-stimulated conditions $(100 \mathrm{ng} / \mathrm{ml})((\mathrm{C})$ and $(\mathrm{D}))$. The $72 \mathrm{~h}$-accumulated medium was collected and lactate concentration was determined. Cultures were allowed to proceed with the corresponding stimuli for an additional $24 \mathrm{~h}$ and $\gamma$-GTP activity was determined on the cells harvested on day 7. Results are expressed as mean \pm S.E.M. of triplicate incubations in one representative experiment out of two. ${ }^{\star} P<0.01$ vs basal or FSH; ANOVA and Tukey's $t$-test. 
Table 1 Effect of bFGF and NGF on basal lactate production and $\gamma$-GTP activity. Sertoli cells were cultured for 3 days in the presence of $10 \mathrm{ng} / \mathrm{ml} \mathrm{bFGF}$ or $10 \mathrm{ng} / \mathrm{ml} \mathrm{NGF}$. The $72 \mathrm{~h}$ accumulated medium was collected and lactate concentration was determined. Cultures were allowed to proceed with the corresponding stimuli for an additional $24 \mathrm{~h}$ and $\gamma$-GTP was determined on the cells harvested on day 7. Results are expressed as a percentage of the basal values and are mean \pm S.E.M. of five separate experiments, each run in triplicate.

\begin{tabular}{lcc}
\hline & $\begin{array}{c}\text { Lactate } \\
(\% \text { basal })\end{array}$ & $\begin{array}{c}\gamma \text {-GTP } \\
(\% \text { basal })\end{array}$ \\
\hline bFGF & $168 \pm 18^{*}$ & $173 \pm 16^{*}$ \\
NGF & $98 \pm 32$ & $103 \pm 12$
\end{tabular}

${ }^{\star} P<0.01$ vs basal; ANOVA and Tukey's $t$-test.

\section{Effect of bFGF and NGF on FSH-stimulated lactate production and $\gamma$-GTP activity}

Figure 1C and D show, in FSH-stimulated cultures, dose-response curves to bFGF and NGF for lactacte production and $\gamma$-GTP activity respectively. FSH-stimulated lactate production and the simultaneous addition of doses higher than $10 \mathrm{ng} / \mathrm{ml}$ of $\mathrm{bFGF}$ produced a synergistic effect. NGF did not further stimulate FSHstimulated lactate production. $\gamma$-GTP activity was stimulated by FSH but neither bFGF nor NGF further increased this enzyme activity at any dose tested.

Figure 2 summarizes the results obtained in five different experiments where the effect of $10 \mathrm{ng} / \mathrm{ml} \mathrm{bFGF}$ or $10 \mathrm{ng} / \mathrm{ml} \mathrm{NGF}$ was tested in combination with $100 \mathrm{ng} / \mathrm{ml} \mathrm{FSH}$.

\section{Effect of bFGF and NGF on transferrin secretion and estradiol production}

Table 2 shows that bFGF stimulated basal transferrin secretion. When bFGF was added to FSH-stimulated

Table 2 Effect of bFGF and NGF on basal and FSHstimulated transferrin (Trf) secretion. Sertoli cells were cultured for 3 days under basal or FSHstimulated conditions in the presence of $10 \mathrm{ng} / \mathrm{ml}$ bFGF or $10 \mathrm{ng} / \mathrm{ml} \mathrm{NGF}$. The $72 \mathrm{~h}$-accumulated medium was collected and transferrin concentration was determined by RIA. Results are expressed as mean \pm S.E.M. of triplicate incubations in one representative experiment out of two.

\begin{tabular}{lcc}
\hline & $\begin{array}{c}\text { Basal } \\
\text { (ng Trf/ } \mu \text { g DNA) }\end{array}$ & $\begin{array}{c}\text { FSH } \\
\text { (ng Trf/ } \mu \text { g DNA) }\end{array}$ \\
\hline Control & $35.1 \pm 3.8^{\mathrm{a}}$ & $61.6 \pm 2.0^{\mathrm{c}}$ \\
bFGF & $80.2 \pm 3.3^{\mathrm{b}}$ & $155.4 \pm 7.8^{\mathrm{d}}$ \\
NGF & $32.9 \pm 1.1^{\mathrm{a}}$ & $59.8 \pm 2.7^{\mathrm{c}}$ \\
\hline
\end{tabular}

Different superscripts indicate statistically significant differences among them $(P<0.01)$; ANOVA and Tukey's $t$-test.
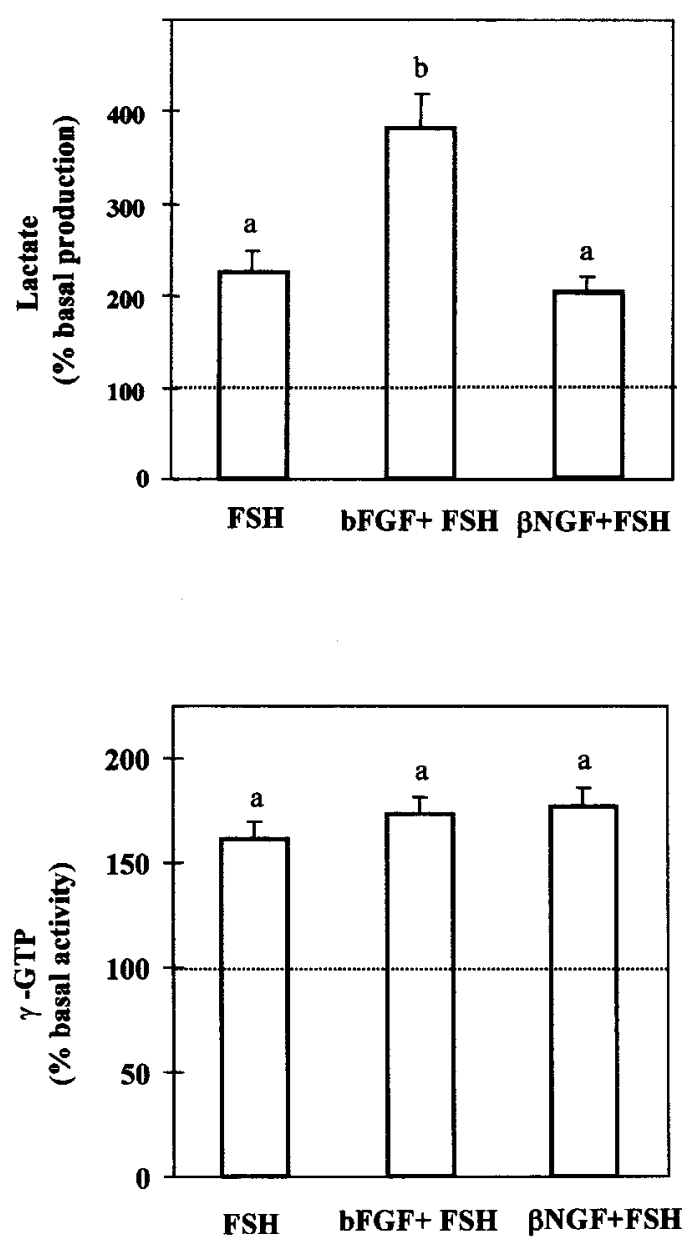

Figure 2 Effect of bFGF and NGF on FSH-stimulated lactate production and $\gamma$-GTP activity. Cells were maintained for 3 days under basal or FSH-stimulated conditions in the presence of $10 \mathrm{ng} / \mathrm{ml} \mathrm{bFGF}$ or $10 \mathrm{ng} / \mathrm{ml}$ NGF. The $72 \mathrm{~h}$-conditioned medium was collected and lactate concentration was determined. Cultures were allowed to proceed with the corresponding stimuli for an additional $24 \mathrm{~h}$ and $\gamma$-GTP activity was determined on the cells harvested on day 7. Results are expressed as a percentage of the basal value and are mean \pm S.E.M. of five separate experiments, each run in triplicate. Different letters indicate statistically significant variation among them $(P<0.01)$; ANOVA and Tukey's $t$-test.

cultures, a synergistic effect was observed. NGF had no effect on transferrin secretion under basal or FSHstimulated conditions.

Finally, to evaluate the effect of bFGF and NGF on estradiol production, Sertoli cells were maintained for 6 days under basal conditions and then stimulated with FSH in the presence of $10 \mathrm{ng} / \mathrm{ml} b F G F$ or $10 \mathrm{ng} / \mathrm{ml}$ NGF. Table 3 shows that both treatments decreased FSHstimulated estradiol production.

\section{Discussion}

By using Sertoli cell cultures, Han et al. (17) and Le Magueresse-Battistoni et al. (29) have shown that bFGF 
Table 3 Effect of bFGF and NGF on estradiol production. Cells were cultured for 6 days in control medium. On the sixth day, cells were stimulated with FSH $(100 \mathrm{ng} / \mathrm{ml})$ and testosterone $(3 \mu \mathrm{mol} / \mathrm{l})$ with the addition of $10 \mathrm{ng} / \mathrm{ml} \mathrm{bFGF}$ or $10 \mathrm{ng} / \mathrm{ml}$ NGF. Twentyfour hours later media were collected and estradiol production was determined by RIA Results are expressed as mean \pm S.E.M. of triplicate incubations in one representative experiment out of three.

\begin{tabular}{lc}
\hline & $\begin{array}{c}\text { Estradiol production } \\
\left(\mathrm{pg}_{2} / \mu \mathrm{g} \mathrm{DNA}\right)\end{array}$ \\
\hline Control & $48.2 \pm 2.1$ \\
$\mathrm{bFGF}$ & $32.0 \pm 1.6^{*}$ \\
$\mathrm{NGF}$ & $36.1 \pm 2.1^{*}$ \\
\hline${ }^{*} P<0.01$ vs control; ANOVA and Tukey's \\
$t$-test.
\end{tabular}

exerts modulatory actions on several parameters of Sertoli cell function. These actions are consistent with the presence of bFGF receptors in Sertoli cells (29). Mullaney and Skinner (30) have shown that bFGF gene expression is predominant early in prepubertal testicular development. These authors have also shown that cultured Sertoli and peritubular cells produce bFGF-like proteins and that, in Sertoli cells, bFGF gene expression and protein production are increased by FSH treatment. From this point of view, metabolic actions of bFGF on Sertoli cells probably represent autocrine regulation or peritubular cell paracrine regulation of the Sertoli cell function. However, other authors have shown by immunohistochemical techniques, Western blot and gene expression analysis that bFGF is produced by germ cells, particularly spermatocytes $(17,31)$. In this case, metabolic actions of bFGF on the Sertoli cell function might represent germ cell-Sertoli cell paracrine interactions as postulated by Han et al. (17).

The other polypeptidic factor assayed on Sertoli cell metabolism was NGF. The cellular type involved in its production remains to some extent a matter of controversy. In situ hybridization studies have shown that NGF mRNA is localized in spermatocytes and round spermatides. Also, NGF protein was detected in these latter cell types by immunohistochemical studies $(19,21)$. On the contrary, in 1996 Seidl et al. (22) showed that Leydig, peritubular and Sertoli cells are the source of this peptidic factor. As for the NGF receptor, Seidl et al. (22) showed that gene expression for trkA, the high affinity receptor for NGF, is present in Sertoli cells. In this way, metabolic actions of NGF on Sertoli cell cultures might represent paracrine or autocrine regulation of Sertoli cell function.

In the present study, we have confirmed the modulatory action that bFGF has on transferrin secretion (17). In addition, we have observed that bFGF has a marked stimulatory effect on $\gamma$-GTP activity and on lactate secretion under basal conditions. Lan et al. (32) have shown that in the initial segment of the rat epididymis bFGF is involved in the regulation of $\gamma$-GTP activity. The results obtained on Sertoli cell $\gamma$-GTP activity are in agreement with this recent study in epididymis. Hinton et al. (33) have proposed that epididymal $\gamma$-GTP may function to protect spermatozoa from oxidative stress in the epididymal duct and/or to recover extracellular cysteine for the synthesis of epididymal proteins. A similar function for this enzyme activity in Sertoli cells might be proposed. Conclusive evidence showing that this enzyme activity is essential for normal sexual development has been obtained in $\gamma$-GTP-deficient mice (34).

Transferrin secretion, lactate production and $\gamma$-GTP activity are responsible of iron delivery, energy provision and maintenance of glutathione levels for germ cell development. The stimulatory actions that bFGF exerts on these parameters of Sertoli cell function suggest that this peptide may represent one of the paracrine/ autocrine messages destined to improve nutrient and energy provision and to increase defense mechanisms in Sertoli cells so that germ cell development can proceed normally.

Combination of bFGF with FSH treatment did not produce further increments in $\gamma$-GTP activity. However, for lactate production and transferrin secretion, a synergistic effect of this peptide with FSH was observed. A synergistic effect of FSH with bFGF has already been observed for plasminogen activator secretion in porcine Sertoli cell cultures (35).

bFGF actions are mediated through specific receptors belonging to the transmembrane tyrosine kinase family. In rat Sertoli cells, gene expression of FGF-R-1 is up-regulated by FSH as well as by dbcAMP (29). On the other hand, Jaillard et al. (35) have shown that bFGF treatment in porcine Sertoli cells increases the number of FSH receptors. The observed synergistic effects of bFGF and FSH on lactate and transferrin secretion might reflect the combined effects of these peptides on their receptors.

The effects of NGF on Sertoli cell IL-6 secretion have been mentioned in the introduction (24). To our knowledge, no other data are available on the effects that NGF might have on Sertoli cell cultures. Our study shows that NGF has no effect on basal and FSHstimulated $\gamma$-GTP activity, lactate production or transferrin secretion. The possibility that the polypeptidic factor utilized in these experiments was devoid of biological activity was ruled out by the fact that under the same experimental conditions NGF inhibited aromatase activity.

Recent observations made by Sharpe et al. (36) in rather elegant experiments have led to the conclusion that prolonged exposure of Sertoli cells to estrogens impairs or delays their functional maturation. In this context, the inhibitory effect of bFGF and NGF on estradiol production may represent signals destined to shut down aromatase activity. 
In summary, it has been shown that a very complex interaction of several growth factors together with FSH and testosterone seem to be necessary for a proper regulation of Sertoli cell function. Our results provide evidence of the participation of bFGF and NGF in the regulation of Sertoli cell aromatase activity. In addition, they provide evidence of the participation of bFGF as regulator of those Sertoli cell functions related to energy provision and maintenance of glutathione levels, functions which are probably essential for normal germ cell development.

\section{Acknowledgements}

The authors wish to thank the National Hormone and Pituitary Program, National Institute of Diabetes, Digestive and Kidney Diseases (NIDDK), Bethesda, MD, USA, for the gift of o-FSH. The technical help of Mercedes Astarloa is gratefully acknowledged.

This work was supported by grants from CONICET and Agencia Nacional de Promoción Científica y Tecnológica, Argentina. HFS and SBC are established investigators of CONICET. SBM is a recipient of a postdoctoral fellowship of the Fundación de Endocrinología Infantil de Buenos Aires, Argentina.

\section{References}

1 Skinner MK. Cell-cell interactions in the testis. Endocrine Reviews $19911245-77$.

2 Jégou B. The Sertoli cell. Baillière's Clinical Endocrinology and Metabolism 19926 273-311.

3 Jutte NHPM, Jansen R, Grootegoed JA, Rommerts FFG \& Van der Molen HJ. FSH stimulation of the production of pyruvate and lactate by rat Sertoli cells may be involved in hormonal regulation of spermatogenesis. Journal of Reproduction and Fertility 198368 219-226.

4 Oonk RB, Jansen R \& Grootegoed JA. Differential effects of folliclestimulating hormone, insulin, and insulin-like growth factor I on hexose uptake and lactate production by rat Sertoli cells. Journal of Cellular Physiology 1989139 210-218.

5 Borland K, Mita M, Oppenheimer CL, Blinderman LA, Massague J, Hall PF et al. The actions of insulin-like growth factors I and II on cultured Sertoli cells. Endocrinology 1984114 240-246.

6 Esposito G, Keramidas M, Mauduit C, Feige JJ, Morera AM \& Benahmed M. Direct regulating effect of transforming growth factor- $\beta 1$ on lactate production in cultured porcine Sertoli cells. Endocrinology 1991128 1441-1449.

7 Nehar D, Mauduit C, Boussouar F \& Benahmed M. Tumor Necrosis Factor- $\alpha$-stimulated lactate production is linked to lactate dehydrogenase A expression and activity increase in porcine cultured Sertoli cells. Endocrinology $19971381964-$ 1997.

8 Kosower NS \& Kosower EM. The glutathione status of cells. International Review of Cytology 197854 109-160.

9 Sies H. Strategies of antioxidant defense. European Journal of Biochemistry 1993215 213-219.

10 Tate SS \& Meister A. $\gamma$-Glutamyl transpeptidase: catalytic, structural and functional aspects. Molecular and Cellular Biochemistry $198139357-368$.

11 Hanigan MH \& Ricketts WA. Extracellular glutathione is a source of cysteine for cells that express gamma-glutamyl transpeptidase. Biochemistry $1993326302-6306$.
12 Schteingart HF, Cigorraga SB, León M, Moya S, Pellizzari E, Chemes $\mathrm{H}$ et al. Hormonal regulation of rat testicular $\gamma$-glutamyl transpeptidase 'in vivo' and 'in vitro'. Andrologia $198820351-$ 359.

13 Schteingart HF, Rivarola MA \& Cigorraga SB. Hormonal and paracrine regulation of $\gamma$-glutamyl transpeptidase in rat Sertoli cells. Molecular and Cellular Endocrinology 198967 73-80.

14 Gnessi L, Fabbri A \& Spera G. Gonadal peptides as mediators of development and functional control of the testis: An integrated system with hormones and local environment. Endocrine Reviews $199718541-609$.

15 Golfarb M. Functions of fibroblast growth factors in vertebrate development. Cytokine Growth Factor Reviews $19967331-325$.

16 Smith EP, Hall SH, Monaco L, French FS, Wilson EM \& Conti M. A rat Sertoli cell factor similar to basic fibroblast growth factor increases c-fos messenger ribonucleic acid in cultures Sertoli cells. Molecular Endocrinology 19893 954-961.

17 Han IS, Sylvester SR, Kim KH, Schelling ME, Venkateswaran S, Blanckaert VD et al. Basic Fibroblast Growth Factor is a testicular germ cell product which may regulate Sertoli cell function. Molecular Endocrinology 19937 889-897.

18 Levi-Montalcini R. The nerve growth factor 35 years later. Science $19872371154-1162$.

19 Ayer-Le Lievre C, Olson L, Ebendal T, Hallbook F \& Persson H. Nerve growth factor mRNA and protein in the testis and epididymis of mouse and rat. Proceedings of the National Academy of Sciences of the USA $1988852628-2632$.

20 Persson H, Ayer-Le Lievre C, Soder O, Villar MJ, Metsis M, Olson L et al. Expression of $\beta$-nerve growth factor receptor mRNA in Sertoli cells downregulated by testosterone. Science 1990247 704-707.

21 Parvinen M, Pelto-Huikko M, Soder O, Schultz R, Kaipia A, Mali P et al. Expression of $\beta$-nerve growth factor and its receptor in rat seminiferous epithelium: specific function at the onset of meiosis. Journal of Cell Biology 1992117 629-641.

22 Seidl K, Buchberger A \& Erck C. Expression of nerve growth factor and neurotrophin receptors in testicular cells suggest novel roles for neurotrophins outside the nervous system. Reproduction, Fertility and Development 19968 1075-1087.

23 Lonnerberg P, Soder O, Parvinen M, Ritzén EM \& Persson H. $\beta$-Nerve growth factor influences the expression of androgenbinding protein messenger ribonucleic acid in the rat testis. Biology of Reproduction 199247 381-388.

24 Stéphan JP, Syed V \& Jégou B. Regulation of Sertoli IL-1 and IL-6 production in vitro. Molecular and Cellular Endocrinology 1997134 109-118.

25 Orlowsky M \& Meister A. $\gamma$-Glutamyl-p-nitroanilide: a new convenient substrate for determination and study of L- and D- $\gamma-$ glutamyltranspeptidase activities. Biochimica et Biophysica Acta $196373679-681$.

26 Handelsman DJ, Spaliviero JA, Kidston E \& Robertson DM. Highly polarized secretion of inhibin by Sertoli cells in vitro. Endocrinology $1989125721-729$.

27 Labarca C \& Paigen K. A simple, rapid and sensitive DNA assay procedure. Analytical Biochemistry 1980102 344-352.

28 Escobar ME, Rivarola MA \& Bergadá C. Plasma concentration of estradiol $17-\beta$ in premature thelarche and in different types of sexual precocity. Acta Endocrinologica (Copenhagen) 197681 351-361.

29 Le Magueresse-Battistoni B, Wolff J, Morera AM \& Benahmed M. Fibroblast Growth Factor receptor type 1 expression during rat testicular development and its regulation in cultured Sertoli cells. Endocrinology 1994135 2404-2411.

30 Mullaney BP \& Skinner MK. Basic Fibroblast Growth Factor (bFGF) gene expression and protein production during pubertal development of the seminiferous tubule: follicle-stimulating hormone-induced Sertoli cell bFGF expression. Endocrinology $19921312928-2934$.

31 Lahr G, Mayerhofer A, Seid K, Bucher S, Grothe C, Knochel Wet al. Basic fibroblast growth factor (bFGF) in rodent testis. Presence of 
bFGF mRNA and of a $30 \mathrm{kDa}$ bFGF protein in pachytene spermatocytes. FEBS Letters 1992302 43-46.

32 Lan Zi-Jian, Labus JC \& Hinton BT. Regulation of gamma-glutamyl transpeptidase catalytic activity and protein level in the initia segment of the rat epididymis by testicular factors: role of basic Fibroblast Growth Factor. Biology of Reproduction $199858197-$ 206.

33 Hinton BT, Palladino MA, Rudolph D \& Labus JC. The epididymis as protector of maturing spermatozoa. Reproduction, Fertility and Development $19957731-745$.

34 Lieberman MW, Wiseman AL, Shi ZZ, Carter BZ, Barrios R, Ou CN et al. Growth retardation and cysteine deficiency in $\gamma$-glutamyl transpeptidase-deficient mice. Proceedings of the National Academy of Sciences of the USA $1996837923-7926$.
35 Jaillard C, Chatelain PG \& Sáez JM. In vitro regulation of pig Sertoli cell growth and function: effects of Fibroblast Growth Factor and Somatomedin-C. Biology of Reproduction 198737 665-674.

36 Sharpe RM, Atanassova N, McKinnell C, Parte P, Turner KJ, Fisher JS et al. Abnormalities in functional development of the Sertoli cells in rat treated neonatally with diethylstilbestrol: a possible role for estrogens in Sertoli cell development. Biology of Reproduction 199859 1084-1094.

Received 19 March 1999

Accepted 9 July 1999 